J Arid Land (2015) 7(3): 391-402

doi: $10.1007 / \mathrm{s} 40333-015-0002-7$

jal.xjegi.com; www.springer.com/40333

\title{
Dryland agriculture and rangeland restoration priorities in Afghanistan
}

\author{
Michael J JACOBS ${ }^{1 *}$, Catherine A SCHLOEDER ${ }^{2}$, Philip D TANIMOTO ${ }^{3}$ \\ ${ }^{1}$ Texas AgriLife Research, Department of Ecosystem Science \& Management, 2138TAMU, College Station, TX 77843-2138, USA; \\ ${ }^{2}$ Oikos Services, LLC, Fortine, MT 59918, USA; \\ ${ }^{3}$ Conservation Imaging, Inc., Auburndale, Massachusetts 02466, USA
}

\begin{abstract}
Afghanistan is threatened by rangeland degradation. A quantitative visual analysis of Google Earth Imagery was used to systematically locate, characterize and quantify the current extent of rangelands in Afghanistan degraded as a consequence of dryland agriculture. Climate data were used in conjunction with dryland agriculture locations to establish a climate envelope comprised by temperature and mean annual precipitation to create a geographical mask known to contain dryland agriculture. Within this mask we created a grid of $100 \mathrm{~km}^{2}$ cells that we analyzed individually to access dryland agriculture extent. Climatic limits to sustainable dryland agriculture and areas of high restoration priority were also assessed as was the distribution of rain-fed agriculture with respect to the location of traditional migration routes for extensive livestock producers. The extents of agriculture in Afghanistan, at both upper and lower elevations, correlated most closely with mean annual temperature (MAT) at the upper elevation limits, and with mean annual precipitation (MAP) at the lower elevation limits. In total, dryland agriculture comprised $38,980 \mathrm{~km}^{2}$ of former native rangeland. Conversion was highest in the northwestern, northern and northeastern provinces of Herat, Badghis, Faryab, Jawzjan, Sar-e-Pul, Samangan, Balkh, Baghlan, Kunduz, Takhar and Badakhshan, with the highest percentage of conversion occurring in Takhar. An MAP value of $<400 \mathrm{~mm}$ is perceived by farmers as the current climatic limit to sustainable dryland agriculture across the northern regions of the country. Uder this MAP value, approximately $27,677 \mathrm{~km}^{2}$ of converted rangeland met the need for restoration priority. Climate projections indicate that Afghanistan will become warmer and drier in the coming decades. One consequence of this trend is that the MAP threshold of $<400 \mathrm{~mm}$ to sustainable dryland agriculture will become obsolete in the coming decades. Restoration of currently converted rangelands is needed to restore critical grazing areas as is the adoption of prudent range management policies to prevent further land degradation and support a vital livestock industry. Food security is at stake as the conversion of rangelands to unsustainable rain-fed agriculture may leave large tracks of land unusable for either agriculture or livestock production.
\end{abstract}

Keywords: degradation; climatic trends; extensive livestock production; dryland agriculture; rangeland restoration

Citation: Michael J JACOBS, Catherine A SCHLOEDER, Philip D TANIMOTO. 2015. Dryland agriculture and rangeland restoration priorities in Afghanistan. Journal of Arid Land, 7(3): 391-402. doi: 10.1007/s40333-015-0002-7

Rangeland degradation in semi-arid and arid rangeland landscapes and the causes leading to degradation have been of concern and debate among range scientists for several decades. Globally, it is estimated that $10 \%-20 \%$ of the world's rangelands are already degraded (Reynolds et al., 2007; Davies et al., 2012). The most cited causes of degradation are overgrazing, dryland agriculture, fuel wood collection and a lack of government policies or regulations (Formoli, 1995; Dregne, 2000; Eswaran et al., 2001; Teketay, 2001; Asner et al., 2004; Rosales and Livinets, 2005; Wilcox and Thurow, 2006; Muller et al., 2007; Wessels et al., 2007; Wilcox, 2007; Harris, 2010). Countries experiencing conflict or post-conflict insecurity more complex situation because historic, community based natural resource management practices may not present

\footnotetext{
*Corresponding author: Michael J JACOBS (E-mail: 2mjjacobs@gmail.com)

Received 2014-04-02; revised 2014-12-06; accepted 2014-12-22

(C) Xinjiang Institute of Ecology and Geography, Chinese Academy of Sciences, Science Press and Springer-Verlag Berlin Heidelberg 2015
} 
an even longer exist, or be confounded by new and multiple challenges (Bedunah and Angerer, 2012; Jacobs and Schloeder, 2012a). The relationships between poverty, conflict and food security, and rangeland degradation, in the context of existing weather patterns and potential climatic trends, are now at the forefront of concern (Savage et al., 2009; Verner, 2010).

Afghanistan is a land-locked country characterized by cold winters and hot dry summers, and an abundance of rangelands that are sparse, dry and seasonal (Thieme, 2006). An additional character of the country is its variability in elevation, ranging from 258 to $7,492 \mathrm{~m}$ asl (Fig. 1). A population estimate in 2011 indicated $79 \times 10^{6}$ resi- dents, and today, over $75 \%$ of residents continue to live in rural areas, while $5 \%$ remain engaged exclusively in extensive livestock production (both transhumant and nomadic pastoralism; MRRD, 2007; World Bank, 2012). The Human Development Report, 2011, ranked Afghanistan $172^{\text {nd }}$ out of 187 countries in poverty. Thirty six percent of the population is estimated to live below the poverty line, while $70 \%$ of the population is considered food insecure (IFAD, 2012). With $84 \%$ of the poor living in rural areas, poverty is predominantly a rural phenomenon (AISA, 2012).

There are approximately $7.94 \times 10^{4} \mathrm{~km}^{2}$ of potentially arable land in Afghanistan out of $6.5 \times 10^{5} \mathrm{~km}^{2}$; and $5.0 \times 10^{4} \mathrm{~km}^{2}$ of potentially irrigable land,

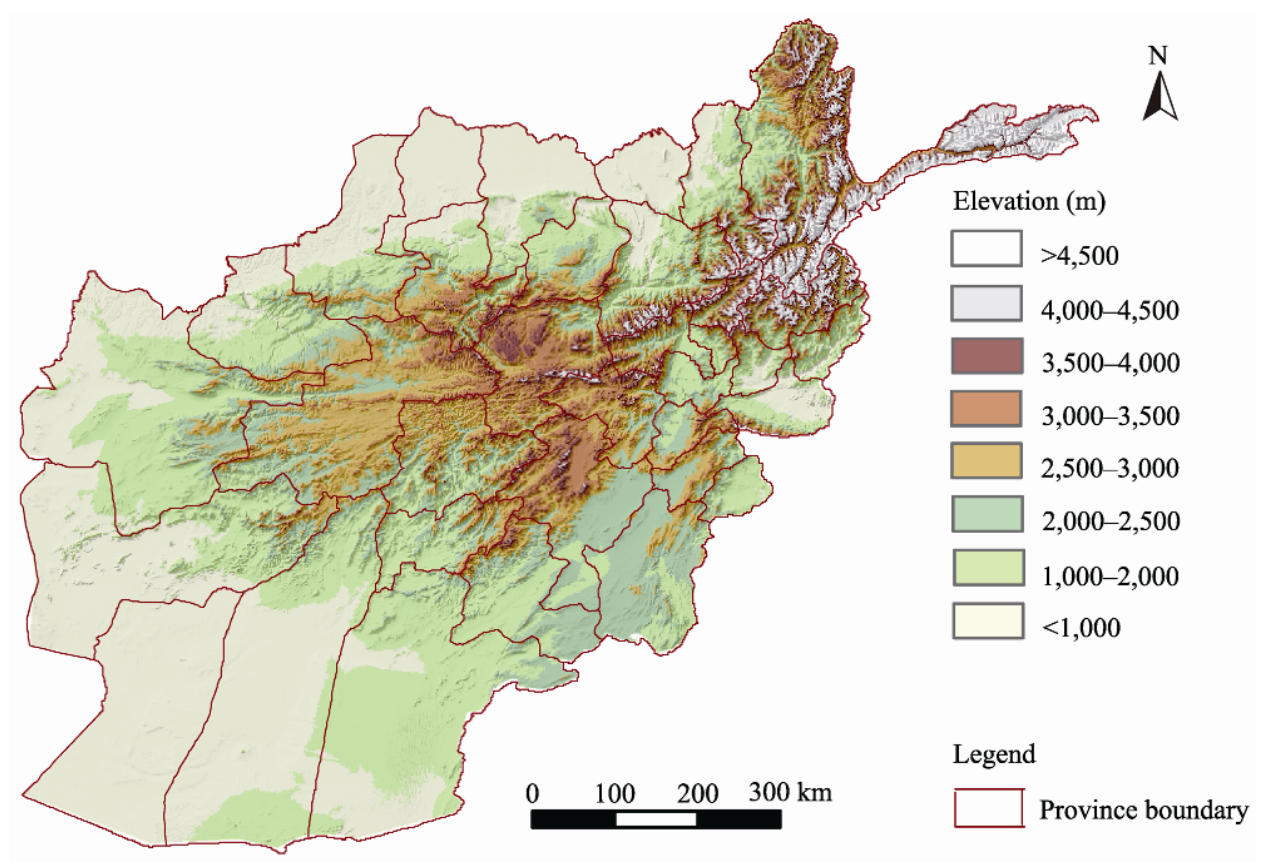

Fig. 1 Elevation variation across Afghanistan

$2.6 \times 10^{4} \mathrm{~km}^{2}$ of which has already been developed (USDA, 2012a). Wheat production generally accounts for $70 \%$ of total cereal production in the country, and estimates of wheat production from dryland cultivation range from $30 \%$ to $45 \%$, depending on the year surveyed (USDA, 2012b). In contrast, Tanimoto et al. (2013) estimates total area of rangelands at $5.83 \times 10^{5}$ $\mathrm{km}^{2}$. Currently, extensive livestock production continues to be the primary use of rangelands with herders using the majority of the landscape to graze their livestock on a seasonal basis (Bedunah, 2006; MRRD,
2009; Schloeder and Jacobs, 2010). Collectively, these figures indicate a high dependency on rangelands by agro pastoralists as well as pastoralists.

The dependency on dryland wheat production is considered one of the more important current driving forces associated with the loss of rangelands in the country and conflicts between herders and farmers (NCSA, 2009; Emadi, 2012; Jacobs and Schloeder, 2012a; Schütte, 2012). Afghanistan's extensive livestock producers, who supply the majority of all small livestock sold in the country's livestock markets, are 
the ones who end up losing the most in the struggle to exploit this natural resource (Desta, 2009; Desta and Schloeder, 2010; Schloeder and Jacobs, 2010). The pressure to find grazing areas is further exacerbated by the lack of clear land tenure policy, lack of governance, and insecurity all of which continue to plague the country. In recent years, there has been some indication that the Government wants to improve its livestock industry and restore rangeland areas (Emadi, 2012; Jacobs and Schloeder, 2012a). Restoration of rangelands will be challenging, however, for various reasons. Foremost is that Afghanistan continues to be one of the poorest and most food-insecure countries in the world (D'Souza, 2011). Another is that since the 1970s, Afghanistan has experienced a series of severe droughts and there is no evidence that this trend will change. While historic climate data for Afghanistan is lacking, data from neighboring countries indicate that Afghanistan's climate has been changing since the 1960s. These include a temperature increase, on average, of $0.29^{\circ} \mathrm{C} / 10 \mathrm{a}$, with most increases occurring in the early spring and summer months and a decline in mean annual precipitation by $2 \% / 10$ a (Savage et al., 2009). Climatic projections for the country indicate that these trends are expected to continue with a $10 \%$ decline in precipitation predicted by 2060 and up to $20 \%$ by 2090 (Savage et al., 2009).

While the need for restoration is agreed upon, there are no data to indicate where cultivation is currently unsustainable, the extent of unsustainable activities, or where restoration should start. In this study, we investigated the current extent of rangeland areas that have been converted to dryland agriculture for the purpose of identifying limits to sustainable dryland cultivation under the current climatic scenario. We also investigated where cultivation is no longer suitable, and therefore, where rangeland restoration and reintroduction of livestock grazing would yield sustainable livelihoods. Implications for rangeland management and food security in Afghanistan, in light of climatic and wheat yield projections for the country, are then discussed.

\section{Data and methods}

A recent nation-wide classification of dryland agriculture using standardized satellite image processing approaches was not available, most likely because this type of agriculture is spectrally similar to the surrounding rangeland vegetation and its phenology appears identical. Senescent rangeland areas and areas with abundant exposed soil can appear virtually identical to cultivated fields on satellite imagery, and security limitations preclude field checking the data. We approached these challenges by performing a systematic quantitative visual analysis of Google Earth Imagery to locate the limits to dryland agriculture and to locate and analyze the extent of rangeland areas that had been converted to dryland cultivation. Google Earth Imagery originates from several sources and is provided to users at various resolutions. Image resolutions for Afghanistan ranged from $30 \mathrm{~m}$ to less than $1 \mathrm{~m}$. Informal discussions with local farmers, a literature review and field surveys in 15 provinces in Afghanistan (http://cnrit.tamu.edu/peace/surveys.html) were then used to evaluate and improve upon the data where possible, and to provide information for discussion. Other spatial data sources used included country data (Afghanistan Information Management Services (AIMS; http://www.aims.org.af), digital elevation data (NASA Aster Program), Google Earth Imagery (2004 and 2005), and 40-year climatic data surfaces (Hijmans et al., 2005). Processing involved downloading and mosaicking 260 digital elevation tiles and clipping the mosaic to the Afghanistan boundary using ArcGIS 9.2 (ESRI, Inc.). Additional spatial data were also developed using ArcGIS and visual image analysis was accomplished using Google Earth (V. 4.5).

\subsection{Analysis area delineation}

We determined which areas of the country had the climatic potential for dryland agriculture by assuming, a priori, that all uncultivated high- and low-elevation non-irrigated areas represented the current maximum and minimum elevation limits to dryland cultivation. Dryland agriculture is generally easy to identify by its distinctive, anthropogenic field edges and lack of irrigation infrastructure. Google Earth Imagery of Afghanistan was visually searched to locate the highestand lowest-elevation limits of this activity. The Google Earth interface automatically provided x, y, and $\mathrm{z}$ coordinates at mouse locations. Approximately ten coordinate sets each, at the upper and lower elevation limits, served as representative maxima and minima of cultivated sites. The coordinates were 
saved as a text file and these points were subsequently located on GIS grids of mean annual temperature (MAT) and mean annual precipitation (MAP; Hijmans et al., 1995). The MAT and MAP raster values at those points were used to represent the upper and lower limits to dryland cultivation, respectively (see Results for justification of selection of these climatic parameters).

\subsection{Quantification of existing rangeland and its conversion to dryland agriculture}

We generated a master vector analysis grid of $10 \mathrm{~km} \times$ $10 \mathrm{~km}$ cells (GIS polygons), which we clipped to the analysis area to define the individual analysis unit subject to visual inspection. Cells of $10 \mathrm{~km} \times 10 \mathrm{~km}$ were selected because they were a suitable size for visual interpretation using Google Earth. Each cell was displayed with its unique polygon ID from the polygon attribute table, which was exported as a spreadsheet. The arcs and label centroids (with polygon IDs) were converted to separate Google Earth KMZ files and overlaid onto the Google Earth Imagery of Afghanistan along with the cell identifier (Fig. 2). An accessory grid which further divided each cell into 8 subunits was used as a spatial reference to help quantify dryland agriculture in areas of particularly complex land cover and topography. In such cases, the 8 subunits were analyzed separately and the mean conversion among them calculated. As needed, we carefully analyzed graphical screen captures, to quantify land cover. Within each cell we conducted the visual survey required to estimate percent cover of rangeland and percent cover of rangeland that had

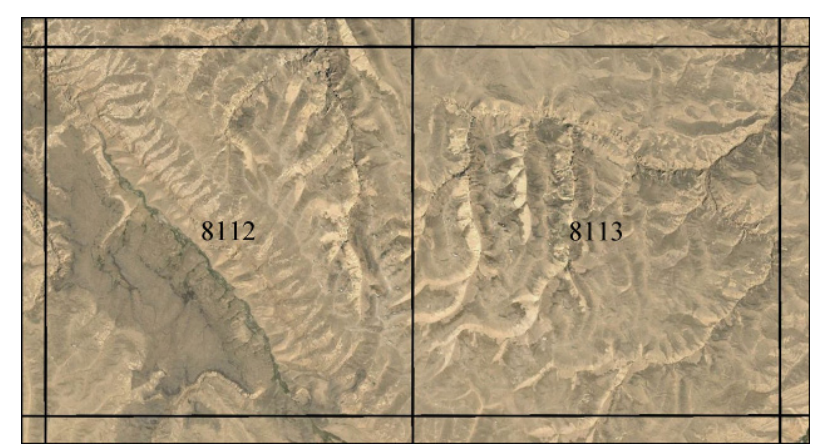

Fig. 2 Two individual analysis units (cells) from the master vector analysis grid overlaid on Google Earth imagery used to visually quantify rangeland and cultivated areas. Each cell is $10 \mathrm{~km}$ on a side and the numbers are the unique polygon IDs of each cell. been converted to dryland agriculture. These two attributes were entered beside the polygon ID in a spreadsheet. Cells that were fragmented into 2 or more subunits by the analysis area boundary were treated as single composite entities and the corresponding redundant spreadsheet rows were deleted. Urban areas, irrigated agriculture, forest with greater than $20 \%$ crown closure, barren ground and rock were not considered rangeland.

Following the visual analysis of all cells, we used the spreadsheet data to calculate the area and percent of rangeland occurring and rangeland converted to dryland agriculture for each cell. All spread sheet data were then imported into the master GIS analysis polygons as attributes, using the cell identifiers as the join item to enable nationwide spatial analysis.

\subsection{Defining areas of dryland agriculture assumed to be unsustainable in Afghanistan}

Dryland agriculture is variously defined: by the number of growing days (1-179 days; FAO, 2000); the maximum amount of precipitation received (500-750 mm annually, with the amount dependent on whether or not the distribution of precipitation is unreliable; Hedge, 1995); and the annual precipitation-to-potential evapotranspiration (P/PET) ratio (between 0.05 and 0.65 ; UNCCD, 2000). Given the variability in definition, we elected to establish what the climatic limit to dryland agriculture was by asking farmers the following question: "How many crop failures do you need to experience in a 5-year period before abandoning cultivation of a site?" We used the geographic locations of 20 fields that had been abandoned due to unreliable precipitation to estimate the MAP limit (s) to sustainable dryland cultivation. Cultivated areas that occurred outside this limit were then deemed in need of restoration as a result of being degraded to varying degrees.

\subsection{Identification of previously cultivated areas in need of restoration}

We prioritized restoration areas according to the relative abundance of unconverted to converted rangeland and the amount of rangeland in each cell. Restoration priority was calculated as the percent of rangeland in dryland agriculture multiplied by the total percentage of rangeland per cell. Areas of lowest restoration priority 
were considered to be those cells having little rangeland in them to begin with regardless of how much had been converted to date, and those cells with a significant amount of rangeland but exhibiting little conversion to date. Areas of highest restoration priority were considered to be those cells that once contained an abundance of rangeland, the majority of which had been converted by the time of this study. For map display, we grouped the restoration priority values into 10 equal classes, with the lowest classes representing lowest priority and upper classes representing highest priority: $1=0-0.10$, $2=0.11-0.20,3=0.21-0.30,4=0.31-0.40,5=0.41-0.50$, $6=0.51-0.60,7=0.71-0.80,8=0.81-0.90$ and $9=0.91-$ 1.0. This coverage was also joined with province polygons to produce provincial summaries. Where provincial boundaries bisected master analysis cells, the percentage of each sub-cell falling into each province was multiplied by the dryland agriculture amounts within the cell to estimate province-specific amounts. This approach provided a means of comparing cells based on both how much rangeland occurs and the percentage converted to dryland agriculture.

\section{Results}

Non-irrigated cultivation was evident at elevations ranging from 272 to $3,823 \mathrm{~m}$. However, at low elevations, such areas often appeared long-abandoned with no evidence of recent agricultural activity. Results indicated that a MAT value of $2.36^{\circ} \mathrm{C}$ was the lowest temperature at which attempts at cultivation could be successful, and a MAP value of $178 \mathrm{~mm}$ was most closely associated with lower elevation attempts. Within these parameters, the initial analysis area totaled $421,524 \mathrm{~km}^{2}$ ( $65.46 \%$ of the country). The presence of snow cover in 8 cells prevented their analysis, yielding 4,690 complete or partial $100 \mathrm{~km}^{2}$ cells for analysis and reducing the area analyzed to $420,724.5$ $\mathrm{km}^{2}$. This area included virtually all dryland agriculture. During cell-by-cell inspection, 404,780 $\mathrm{km}^{2}$ $(96.2 \%)$ of the analysis area was visually interpreted as rangeland and dryland agriculture was estimated at $45,102 \mathrm{~km}^{2}$ or $11.14 \%$ of rangelands evaluated. For map display, these quantities were grouped into ten classes, with cells exhibiting less than $10 \%$ conversion assigned to Class 1, and cells exhibiting 90\% conversion assigned to Class 10 (Fig. 3).

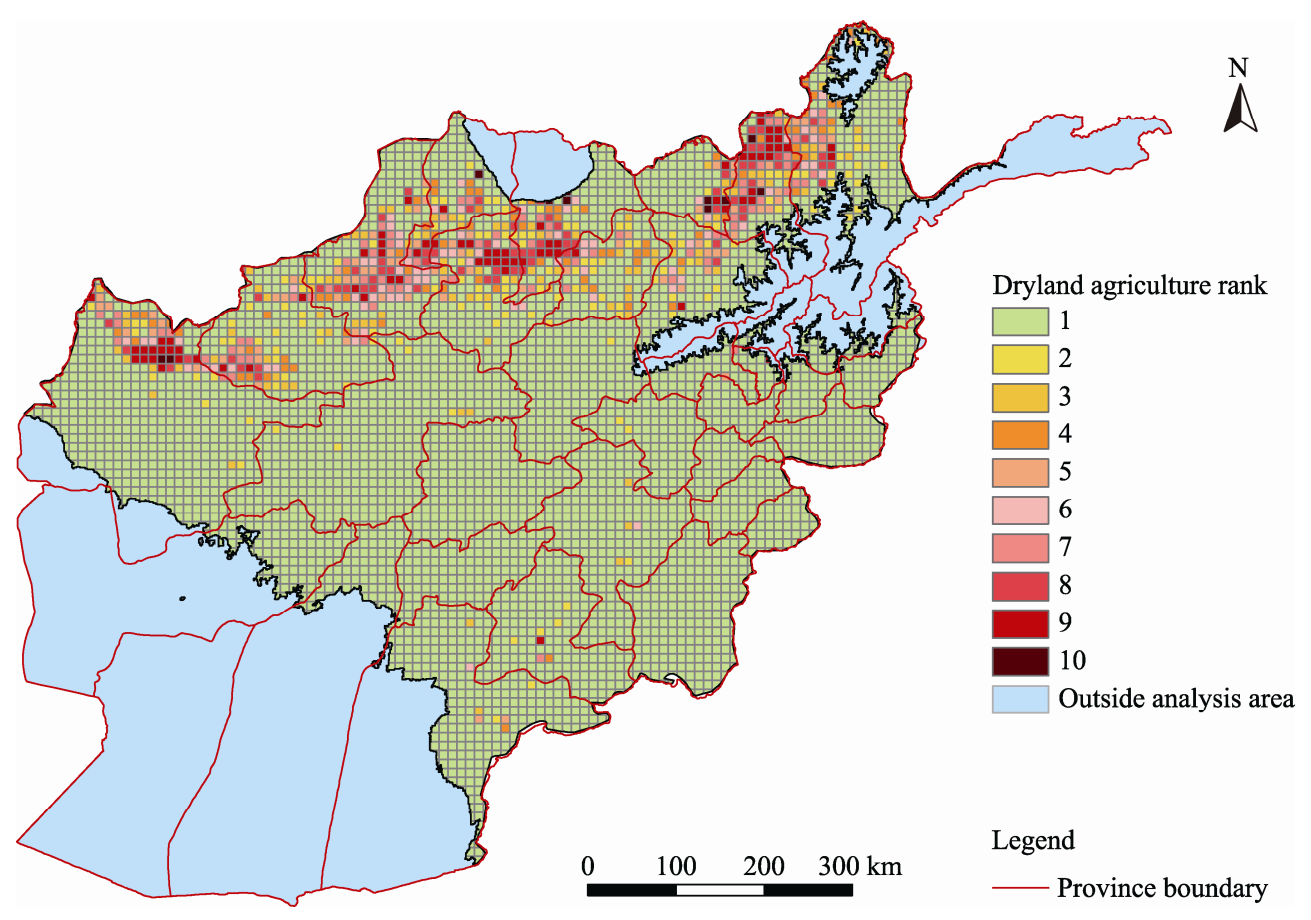

Fig. 3 Percent of rangeland conversion, per $10 \mathrm{~km} \times 10 \mathrm{~km}$ cell, resulting from dryland agriculture in Afghanistan. Conversion class key: $1=1 \%-10 \%, \quad 2=11 \%-20 \%, 3=21 \%-30 \%, \quad 4=31 \%-40 \%, \quad 5=41 \%-50 \%, \quad 6=51 \%-60 \%, \quad 7=61 \%-70 \%, \quad 8=71 \%-80 \%, \quad 9=81 \%-90 \%$, $10=91 \%-100 \%$. 
Attempts at dryland cultivation were most common all across northern Afghanistan, in Herat, Badghis, Faryab, Jawzjan, Sar-e-Pul, Samangan, Balkh, Baghlan, Kunduz, Takhar and Badakhshan provinces, with the highest percentage having occurred in Takhar province. The interviews with farmers revealed that they would abandon further efforts to cultivate a site if they experienced three crop failures within a 5-year period of cultivation. We determined that MAP values of $<400 \mathrm{~mm}$ were most closely correlated with aban- donment as a result of this "farmers rule". Removing all cultivated areas receiving $\geq 400 \mathrm{~mm}$ MAP from the total area under dryland cultivation led to a conservative estimate of approximately $27,677 \mathrm{~km}^{2}$ of rangeland that had been subjected to attempts at cultivation under insufficient or unreliable precipitation conditions (Fig. 4). These included the lower elevation areas of Herat, Badghis, Faryab, Jawzjan, Sar-e-Pul, Samangan, Balkh, Baghlan, Kunduz, Takhar and Badakhshan provinces.

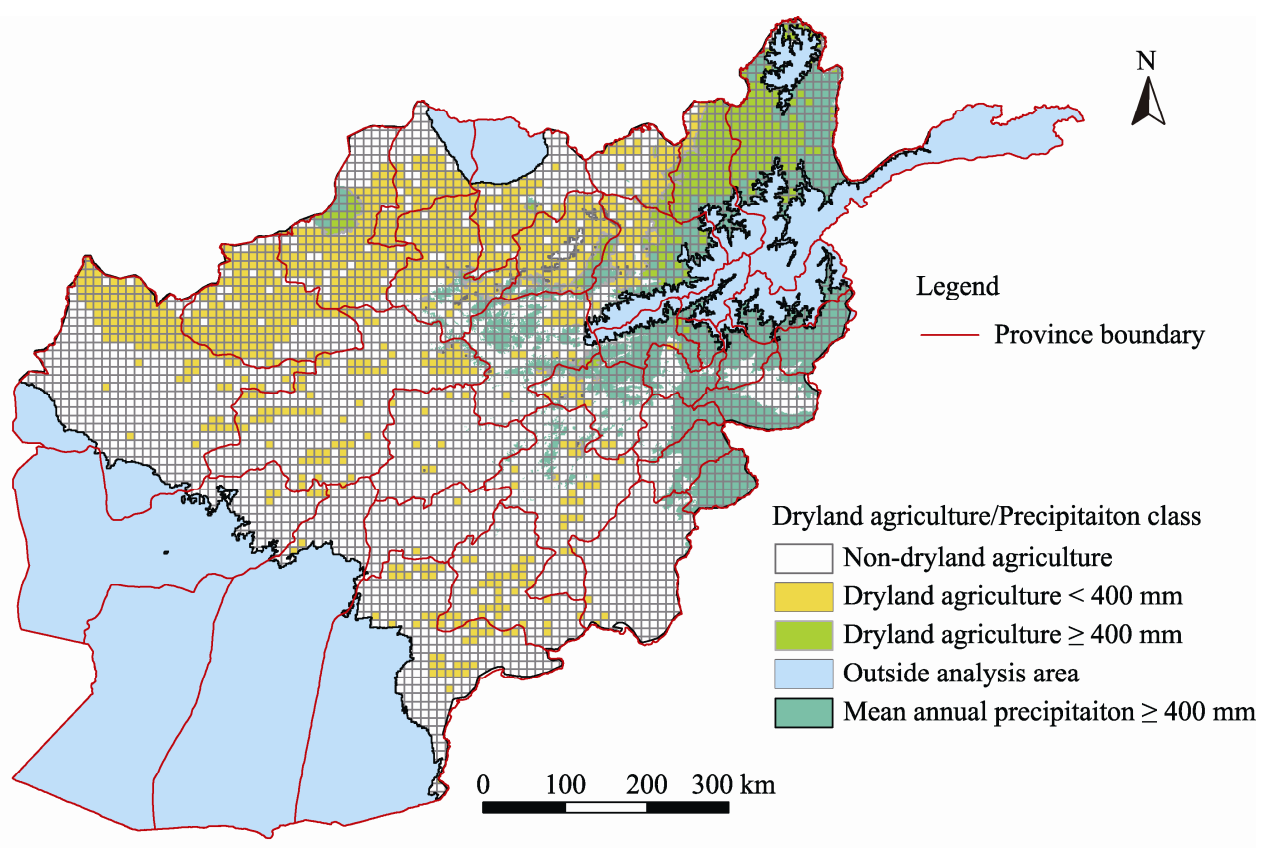

Fig. 4 Precipitation classes ( $<400 \mathrm{~mm}$ and $\geq 400 \mathrm{~mm}$ ) and distribution of dryland agriculture across Afghanistan

After prioritizing the data, we identified 18 districts in eight provinces where restoration appeared of highest priority (Fig. 5): Herat province (Kushk, Gulran and Kushki); Badghis province (Qala-I-Naw); Faryab province (Qaysar and Pashtun Kot); Jawzjan province (Darzab); Sar-e-pul province (SozmaQala, Sang Charak and Gosfandi); Balkh province (Chimtal and Sholgara); Kunduz province (Khan Abad); Takhar province (Baharak, Rustaq, Hazar Sumuch, KhwajaGhar and Dasht-e Qala).

\section{Discussion}

Afghanistan's climate is classified as arid or semi-arid steppe. This classification is the result of a lack of moisture-laden winds reaching the country due to its being land-locked, the effect of distance from maritime sources, and neighboring mountain massifs which trap any moisture moving inland. A characteristic of this climate type is normally quite extreme weather events including very cold and snowy winters, very hot and dry summers and periodic droughts that are frequently of long duration. When precipitation occurs, it is generally during the late fall (lowland areas), early winter (higher elevations) and early spring, with the majority falling on higher elevations rather than the lowland plains and plateaus. The resulting MAP value of $\geq 400 \mathrm{~mm}$ as the lower threshold to sustainable agriculture, in the country's lowland areas, is therefore not surprising. 


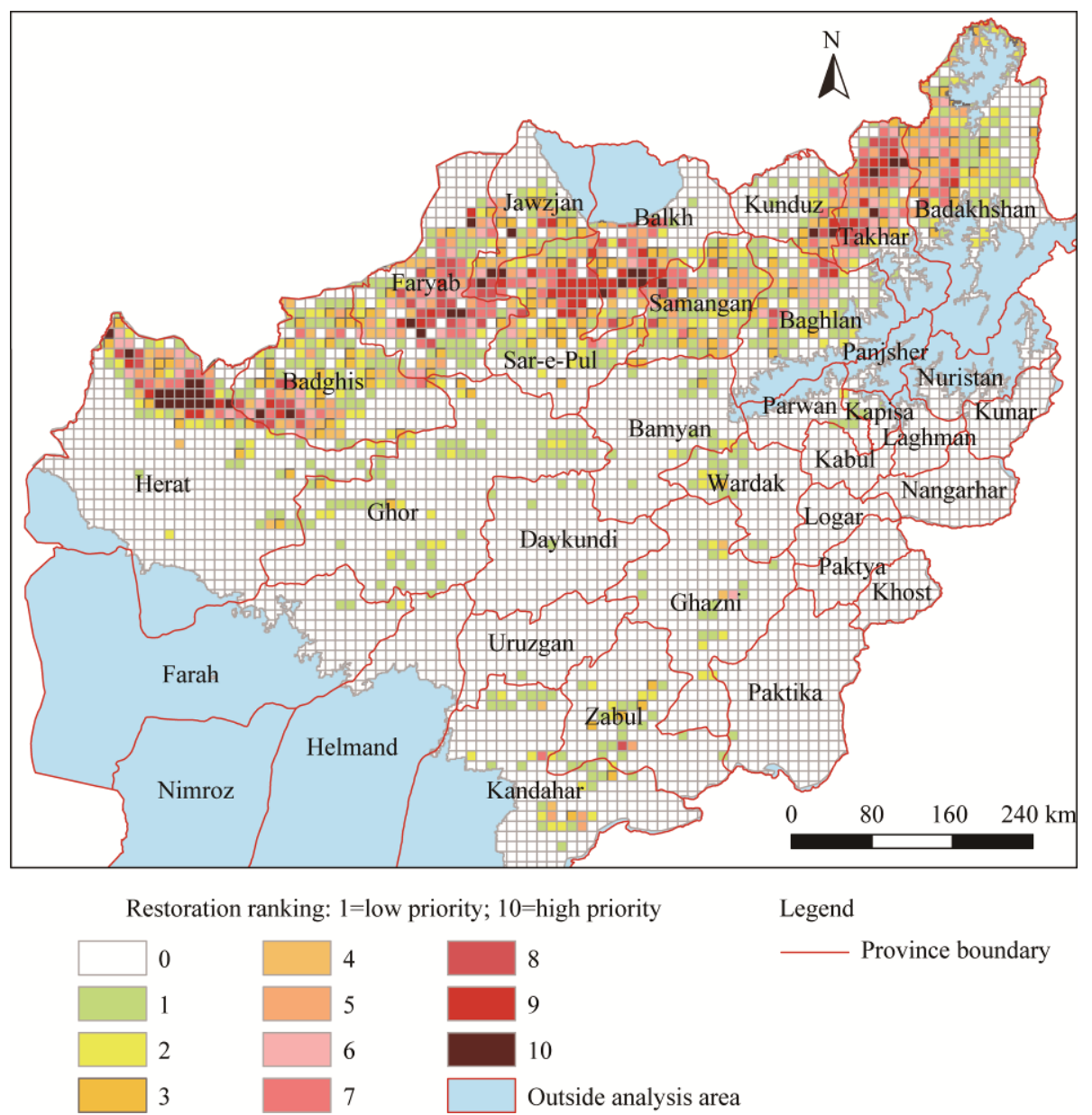

Fig. 5 Areas in Afghanistan that are need of restoration due to unsustainable dryland agriculture attempts. Ranking of restoration priority per $10 \mathrm{~km} \times 10 \mathrm{~km}$ cell is displayed as: lower numbered areas are of lower priority and higher numbered areas are considered higher priority.

Despite consistently unpredictable precipitation conditions, the drive to cultivate in rural areas is great and has had considerable impact on Afghanistan's dry rangeland areas, particularly across the northern lowland areas. Over $30 \%$ of rangelands in the analysis area, with the majority occurring in the northern lowland plains areas, showed some degree of cultivation. Attempts at cultivation in unsustainable situations, where MAP averages $<400 \mathrm{~mm}$, was also extensive. As a consequence, there are now a minimum of $27,677 \mathrm{~km}^{2}$ of rangelands in the lowland provinces of Herat, Badghis, Faryab, Jawzjan, Sar-e-Pul, Samangan, Balkh, Baghlan, Kunduz, Takhar and Badakhshan in need of some type of restoration, with some areas in more immediate need than others. Attempts at cultivation in the northern plains are not surprising given that this region of the country typically produces $70 \%$ of the total wheat crop each year, mostly on non-irrigated areas (USDA, 2012b). Precipitation in these areas, however, continues to be unpredictable and forecasts that it will become even more so indicate caution regarding any further attempts at dryland cultivation below this MAP threshold.

To date, dryland agriculture in Afghanistan has occurred in a variety of native vegetation types, including annual to perennial grasslands, open woodlands and shrub lands and in some instances, alpine (Tanimoto et al., 2013). In contrast, the majority of unsustainable agriculture has occurred primarily in the annual to perennial grassland types found below $2,000 \mathrm{~m}$ in elevation. The lowland native grasslands areas, regardless of being perennial or annual, tend to be sparsely vegetated, possess little liter and an abund- 
ance of bare soil (http://cnrit.tamu.edu/peace/surveys. html). As a consequence of these characteristics, they tend to be more easily disturbed and degraded. In deriving a method for prioritizing rangeland sites for restoration under these conditions, we have assumed $a$ priori that any modification to the soils and vegetation has resulted in the need for some type of restoration, and that rangeland areas that have been almost completely converted by cultivation (within a $10 \mathrm{~km} \times 10$ $\mathrm{km}$ cell) qualify for highest restoration priority. Our justification for these assumptions is that disturbance of a site by cultivation has been shown to result in losses in biodiversity, further declines in organic matter, increases in soil compaction and soil erosion, decreases in soil porosity and increases in runoff, all of which lead to losses of ecosystem function and services (White, 2005).

There are, however, some challenges to restoration. In the event that factors leading to degradation are clear and controllable, degradation has been shown to be reversible (Whisenant, 1999). Cultivated sites in Afghanistan normally experience more than one type of degradation both during and after their tenure of cultivation, however, and these collectively and in combination with the vegetation and soil type can make restoration quite challenging. In light of this, the need for restoration should be based on several other factors including frequency of cultivation prior to abandonment, method of cultivation (animal versus mechanical traction), soil type and geographic extent of cultivation. Additionally, the role of various weather events and anthropogenic activities acting individually or collectively, during and after, are also of import. Activities and events that limit current native vegetation and continue to prevent its natural regeneration include: (1) Intensity and frequency of wind events: these occur annually, are common across all of the northern provinces of Afghanistan in the summer, and of greatest intensity in Herat province; (2) Seasonality and intensity of flood events: these are mostly of irregular occurrence, a spring phenomenon, and most likely to occur in Kunduz, Takhar, Sar-e Pul, Samangan and Badakshan provinces; (3) Frequency and duration of drought: all northern provinces equally susceptible when droughts occur; (4) Removal of live vegetation and dead organic matter for winter fuel (digging, cutting and raking): this occurs most frequently in the fall, just prior to winters' arrival with all northern provinces being equally susceptible; (5) Removal of winter fodder (raking): this occurs most frequently in the fall, just prior to winters' arrival with all northern provinces being equally susceptible; (6) Removal of medicinal plants (digging): this is a seasonal activity that tends to occur during the growing season, across all northern provinces, and is driven by demand both locally and internationally (e.g. India); (7) Frequency, intensity and duration of livestock grazing and browsing: this activity takes place during the growing period (late fall, winter and early spring), when precipitation is most likely and weather conditions allow.

In general, the many native rangeland areas across northern Afghanistan are botanically diverse with very little variation in soils. In contrast, rangeland sites that had been disturbed by cultivation and subsequently abandoned exhibit different vegetation states, some of which include: (1) Sites that had experienced very little tillage (1-2 years only) by animal traction: these were likely to be recolonized by a range of native annual and perennial species if they remained mostly undisturbed post abandonment, with the exception of the tuberous (Lilliaceae, Alliaceae) and woody (suffrutescents included) species. If the depth of tillage was not too great, some of the grasses and Carexs pecies returned post-abandonment as well; (2) Sites tilled for three or more years: these tended to be recolonized mostly by unpalatable and at times toxic annual species of generally low nutritive value (Malcomia turkestana, Papaver decaisnei, Fumaria parviflora and Leptaleum filifolium) regardless of traction type; (3) Sites on saline soils (lowest elevation areas in northern Balkh, Kunduz, Faryab and Jawzjan provinces): these were generally recolonized by monocultures of Salsola brachiata, Halocharis hispida and Halocylon griffithi; (4) Sites that had experienced frequent tillage regardless of traction type, followed by one or more disturbances such as fuel and fodder collection, or sites that were subjected to mechanical traction for two years: these tended to persist in the production of a limited number of annual species unless they also experience done or more weather events (e.g. drought, wind and flood) or were grazed for an extended period 
or repeatedly, in which case compacted bare soil and eroded landscapes eventually became the norm.

The degraded vegetation states described here occur along a spectrum with bare compacted soil at one end and slightly modified native vegetation at the other. Under a static climate scenario, the better condition sites would persist if not degraded further by one or more factors. Both situations are unlikely, however, and as the climate in Afghanistan becomes hotter and drier further degradation with bare soil as the end result is the expected outcome. Acting on the need for restorative measures now is, therefore, critical.

In our investigation we were able to identify where and how many of the countries receive insufficient precipitation to support dryland cultivation, and where and how many rangelands are in need of restoration. It is likely that our estimate is low, however, because Afghanistan is known to experience extreme localized climatic events at times which, if they persist for a number of years, can lead to soil conditions that no longer support cultivation even under previously sustainable precipitation conditions. Potential evapotranspiration rates can vary considerably as well, which means that sites thought to be suitable for dryland agriculture may in fact not be. Herat province, known for having consistent and extreme wind events from June through September, is one area where our estimate of degraded rangelands is most likely too low. Finding the actual limits to sustainable dryland cultivation in areas within this province as well as other provinces with high $\mathrm{P} / \mathrm{PET}$ ratios, would be prudent.

Wheat and livestock production are critical from a food-security perspective. In 2011, wheat and livestock contributed $7.3 \%$ and $14 \%$, respectively, of the agricultural GDP (USDA, 2011). Wheat is also important which makes up 54\% of the populations' diet and this dependency has not appeared to wane even in the face of increasing wheat prices; moreover, it is expected to continue to increase in tandem with population growth (D'Souza, 2011). In contrast, most rural Afghan diets are deficient in protein, and in areas we identified as in need of restoration, protein deficiency commonly affects $40 \%$ or more of the population (World Bank, 2010). The country has achieved some growth in its wheat yields since 2001, with the major- ity of increases coming from seed development and availability of fertilizer (USDA, 2012a). Yields remain low and erratic, however, compared to other countries, due to the sensitivity of this sector to variations in weather and precipitation (D'Souza, 2011). This has not been the case for livestock production despite the fact that pastoralists in Afghanistan are the most common group to receive food aid, and currently, $40 \%$ of their population remains in internally displaced people's camps as a result of having lost all their livestock to drought, land conversions and insecurity (USAID, 2007; USDA, 2011; Jacobs and Schloeder, 2012a). Rather, the contribution of livestock production to GDP has grown modestly in the last decade (World Bank, 2013).

While precipitation can be a limiting factor to extensive livestock production as well, herders in the country have always been better able to manage this risk by tracking forage conditions as they improve or degenerate, selling off animals when conditions are unfavorable, and by economically diversifying (Desta and Schloeder, 2010). This form of production is, therefore, already the most efficient use of lands that are known to be unreliable for dryland agriculture or intensive livestock schemes.

Extensive livestock production should also be considered as a means of addressing both poverty and food security in many currently sustainable dryland agricultural situations. When comparing migration maps from Jacobs and Schloeder (2012a) and Schutte (2012), with the map of restoration priority areas from this study (Fig. 6), it is apparent that many critical grazing and migration areas have been lost to dryland cultivation.

With poverty rates ranging from $25 \%$ to as high as $60 \%$ across the north, and protein deficiency a concern, livestock production could play a more prominent role, in terms of poverty and food security, than it does currently. Additionally, as more and more areas in the country progressively become unsuitable for dryland cultivation (as precipitation declines), Afghanistan will find that extensive livestock production is the only suitable livelihood in many of its landscapes. Therefore, careful consideration of the trade-off between continuing (currently) sustainable dryland 


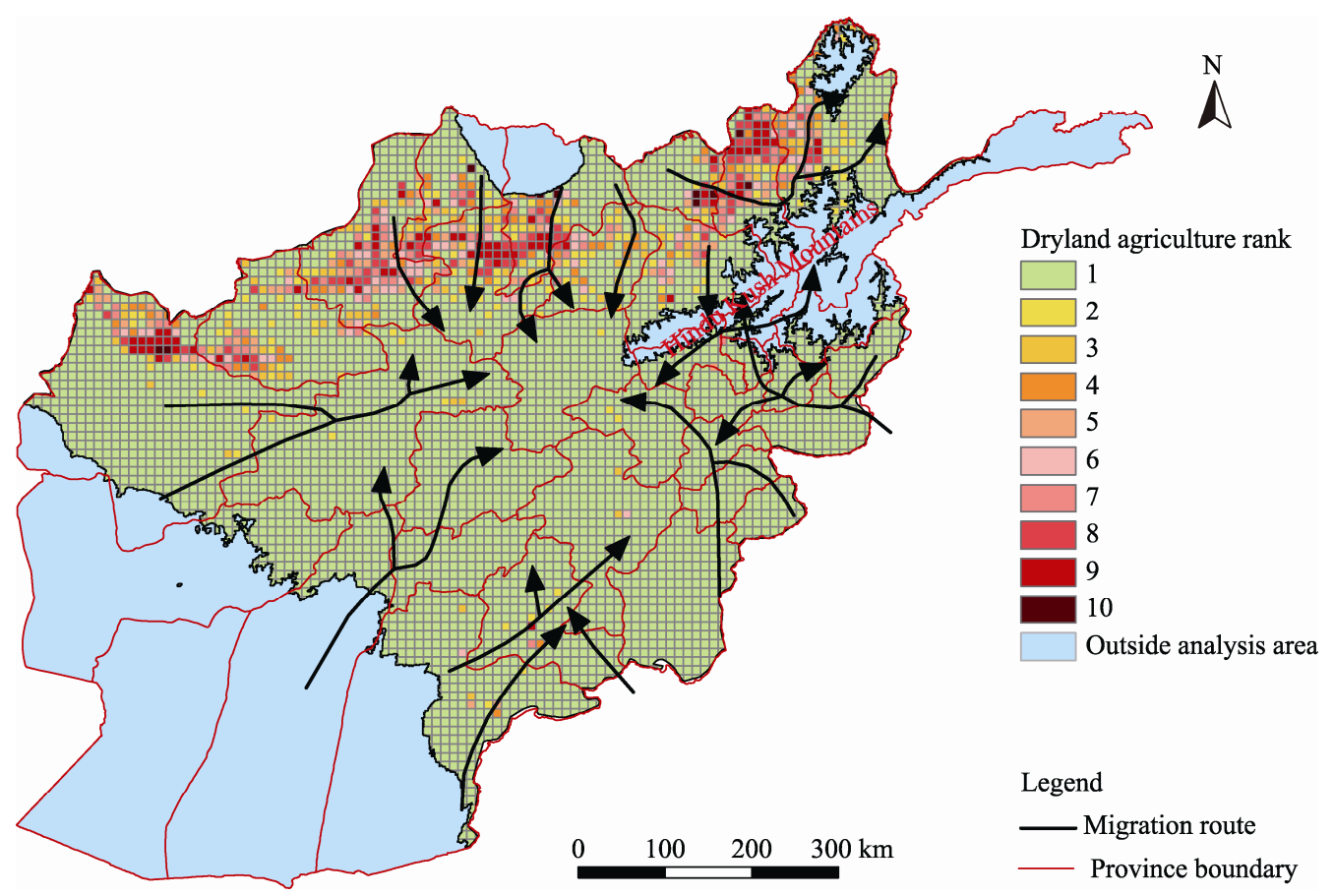

Fig. 6 Extensive livestock migration routes are shown in relation to priority restoration areas. Regions north of the Hindu Kush Mountains present considerable challenges to seasonal movements between winter and summer ranges, along with severely depleted forage conditions.

cultivation in certain areas and extensive livestock production must be made to avoid not only the collapse of this important industry, but more wide-spread environmental degradation as the climate changes. A starting point would be the development of policies which prohibit cultivation of migratory access routes and their associated grazing and water areas, particularly in Taluqan and Kalafgan districts (Takhar province), and Tishkan, Kishim, Darayim and Baharak districts (Badakhshan province).

\section{Conclusions}

Afghanistan is currently facing many challenges when it comes to environmental degradation. The foremost concern is the cultivation of vast areas of vital rangelands. Cultivation is of greatest concern in those areas where precipitation is insufficient to support dryland agriculture. Not only is this activity resulting in widespread environmental degradation, it is also having an impact on a vital livestock industry as well as the livelihood and diets of a large number of people. If unsustainable cultivation continues unchecked, the extent and degree of degradation will increase. If resto- ration efforts are not implemented on existing abandoned sites further degradation can be expected. Also of concern is the cultivation of critical livestock grazing and migratory areas in terms of its current and future impacts on people's livelihoods, livestock production, and critical rangeland ecosystem services and functions, as the country's climate becomes drier.

Dryland cultivation for wheat is intricately tied to food insecurity, poverty and protein deficiency issues in Afghanistan. Therefore, urgently addressing some of the more critical rangeland management issues related to this activity, including rangeland restoration and policy development, is critical. Afghanistan's livestock industry is also intricately tied to food insecurity, poverty and protein deficiency issues. Critical to this industry is access to grazing and migration lands throughout the year. Restoration of degraded areas and limiting cultivation in new areas will go a long way to improving this industry, and support of it will in turn lead to sustainable environmental management, alleviating poverty, and improving access to a local protein source. We advocate the development of a rangeland management strategy which builds 
upon the research presented in this paper. We also advocate immediate action to restore vital rangeland areas across the north. Delaying action will only jeopardize the Governments' ability to manage this resource in the future as more and more people take matters into their own hands in the quest to cope with food and economic insecurity issues. Delays will also make restoration more costly, if not prohibitive, as the extent and degree of degradation increases.

\section{Acknowledgements}

This work was funded by the U.S. Agency for International Development (306-A-00-06-00521-00). It was performed by the Texas A\&M University, in collaboration with the University of California. We are grateful for this support and to the generous people of Afghanistan who facilitated this study. The opinions expressed in this study are from the authors themselves and do not necessarily reflect the views of USAID.

\section{References}

Afghanistan Investment Support Agency (AISA). 2012. Essential facts on economic performance and investment in Afghanistan. [2013-03-06]. http://www.aisa.org.af/brochures/economy-fact-english.pdf.

Afghanistan PEACE Project. 2006-2011. Field surveys. [2009-02-09]. http://cnrit.tamu.edu/peace/surveys.html.

Asner G P, Elmore A J, Olander L P, et al. 2004. Grazing systems, ecosystem responses and global change. Annual Review Environmental Resources, 29: 261-299.

Bedunah D J. 2006. An analysis of Afghanistan's rangelands and management issues for the development of policy and strategies for sustainable management. Chemonics International, Inc. [2006-01-06]. http://pdf.usaid.gov/pdf_docs/PNADG285.pdf.

Bedunah D J, Angerer J P. 2012. Rangeland degradation, poverty, and conflict: how can rangeland scientists contribute to effective responses and solutions? Rangeland Ecology \& Management, 65(6): 606-612.

Davies J, Poulsen L, Schulte-Herbrüggen B, et al. 2012. Conserving dryland biodiversity. United Nations convention to combat desertification. [2012-10-08]. http://www.iucn.org/publications.

Desta S. 2009. Risk management strategy for Kuchi herders in Afghanistan. [2009-01-10].http://cnrit.tamu.edu/peace/pdfs/PEACE\%20Risk\%20As sessment\%20Report\%20Jan\%202009.pdf.

Desta S, Schloeder C. 2010. Report on initiating a pilot communitybased risk management project with the Kuchi in Northern Afghanistan. [2009-01-10]. http://cnrit.tamu.edu/peace/riskmgmt.html.

Dregne H E. 2000. Desertification: problems and challenges. Annals of Arid Zone, 39: 363-371.

D’Souza A. 2011. Rising food prices and declining food security: evidence from Afghanistan. [2011-09-11]. http://www.ers.usda.gov/waves/2011-september/ afghanistan-food-security.aspx.

Emadi M H. 2012. Better land stewardship to avert poverty and land degradation in Afghanistan. In: Squires V. Rangeland Stewardship in Central Asia: Balancing Improved Livelihoods, Biodiversity Conservation and Land Protection. Dordrecht: Springer, 91-108.

Eswaran H, Lal R, Reich P F. 1999. Land degradation: an overview. In: Bridges E M, Hannam I D, Oldeman L R, et al. 1999. Responses to Land Degradation. Proceedings of the $2^{\text {nd }}$ International Conference on Land Degradation and Desertification, 25-29 January 1999, KhonKaen, Thailand. New Delhi: Oxford Press.

FAO. 2000. Land resource potential and constraints at regional and country levels. World Soil Resources Report No. 90. Rome.

Formoli T A. 1995. Impacts of the Afghan-Soviet War on Afghanistan's environment. Environmental Conservation, 22(1): 66-69.

Harris R B. 2010. Rangeland degradation on the Qinghai-Tibetan plateau: are view of the evidence of its magnitude and causes. Journal of Arid Environments, 74: 1-12.

Hegde B R. 1995. Dryland farming: past progress and future prospects. In: Singh R P. Sustainable Development of Dryland Agriculture in India. Jodhpur: Scientific Publishers, 7-12.

Hijmans R J, Cameron S E, Parra J L, et al. 2005. Very high resolution interpolated climate surfaces for global land areas. International Journal of Climatology, 25: 1965-1978.

International Fund for Agricultural Development (IFAD). 2012. Republic of Afghanistan: community livestock and agriculture project programme/project design report-main report. [2014-11-25]. http://www.ifad.org/operations/projects/design/107/af-ghanistan.pdf

Jacobs M J, Schloeder C A. 2012a. Extensive livestock production: Afghanistan's Kuchi herders, risks to and strategies for their survival. In: Squires V. Rangeland Stewardship in Central Asia: Balancing Improved Livelihoods, Biodiversity Conservation and Land Protection. Dordrecht: Springer, 109-127.

Jacobs M J, Schloeder C A. 2012b. First steps in addressing land degradation in Afghanistan. Journal of Arid Land Studies, 22(1): 123-126.

MRRD (Ministry of Rehabilitation and Rural Development and the Central Statistics Office). 2007. National Risk and Vulnerability Assessment 2005. [2013-11-10]. http://home.wfp.org/stellent/ groups/public/documents/ena/wfp193560.pdf.

MRRD (Ministry of Rural Rehabilitation and Development and Central Statistics Office). 2009. National Risk and Vulnerability Assessment 2007/8: A Profile of Afghanistan. Cologne: ICON-Institute GmbH \& Co KG Consulting Gruppe.

Müller B, Frank K, Wissel C. 2007. Relevance of rest periods in non-equilibrium rangeland systems-A modeling analysis. Agricultural Systems, 92: 295-317.

NCSA. 2009. Afghanistan National Capacity Needs Self-Assessment for Global Environmental Management (NCSA) and National Adaptation Programme of Action for Climate Change (NAPA). Final Joint Report.

Reynolds, J F, Smith D M S, Lambin E F, et al. 2007. Global desertification: building a science for dryland development. Science, 316 : 847-851.

Rosales M, Livinets S. 2005. Grazing and land degradation in CIS countries and Mongolia. In: Proceedings of the electronic conference on grazing and land degradation in CIS countries and Mongolia, 10 June-30 July 2005. Rome, Italy: Food and Agriculture Or- 
ganization of the United Nations. 6.

Savage M, Dougherty B, Hamza M, et al. 2009. Socio-Economic Impacts of Climate Change in Afghanistan. Report DFID CNTR 08 8507. Oxford: Stockholm Environment Institute.

Schloeder C A, Jacobs M J. 2010. Afghanistan livestock market assessment: Report on Afghanistan livestock market dynamics October 2008-October 2009. Afghanistan PEACE Project. [2010-06-04]. http://cnrit.tamu.edu/peace/pdfs/PEACE\%20Livestock\%20Marke\% 20Synthesis\%20Report\%20June $\% 202010 \% 20$ web\%20version.pdf.

Schütte S. 2012. Pastoralism, power and Politics. In: Kreutzmann H. Pastoral Practices in High Asia: Agency of "Development" Effected By Modernisation, Resettlement and Transformation. New York: Springer Science+Business Media, 53-70.

Tanimoto P D, Jacobs M J, Schloeder C A. 2013. Current land cover and land use in Afghanistan. [2014-11-15]. http://cnrit.tamu.edu/peace/pdfs/Land_Cover. pdf.

Teketay D. 2001. Deforestation, wood famine, and environmental degradation in Ethiopia's highland ecosystems: urgent need for action. Northeast African Studies, 8: 53-76.

Thieme O. 2006. Afghanistan, Country Pasture/Forage Resource Prof -iles. Rome: Food and Agriculture Organization. [2006-05-15]. http://www.fao.org/ag/AGP/AGPC/doc/Counprof/PDF\%20files/Afg $\neg$ hanistan.pdf.

UNCCD. 2000. An introduction to the United Nations convention to combat desertification. [2012-06-12]. http://www.unced.int./Lists/ OfficialDocuments/cop4/cst5eng.pdf.

USAID (United States Agency for International Development). 2007. Afghanistan food security conditions and causes: a special report by the famine early warning systems network.

USDA (United States Department of Agriculture). 2008. Afghanistan: severe drought causes major decline in 2008/09 wheat production. Commodity intelligence report. Washington, DC: U.S. Department of Agriculture, Foreign Agricultural Service.

USDA. 2011. 2011 Afghan Agricultural Economy Update. Global Agricultural Information Network. Foreign Agricultural Service. [2011-09-09].http://gain.fas.usda.gov/Recent\%20GAIN\%20Publications/
2011\%20Af-ghan\%20Agricultural\%20Economy\%20Update_Kabul _Afghanistan_7-9-2011.pdf.

USDA. 2012a. Long term growth prospects for wheat production in Afghanistan. A report from the economic research service. WHS11L-01. [2012-01-14]. http://www.ers.usda.gov/publications/whswheatoutlook/whs11101.aspx\#.Up0HcsSTh5I.

USDA. 2012b. U.S. Department of agriculture, foreign agricultural service. Afghanistan commodity intelligence report. [2012-05-25]. http://www. pe-cad.fas.usda.gov/highlights/2012/05/Afghanistan.

Verner D. 2010. Reducing poverty, protecting livelihoods, and building assets in a changing climate. International Conference on Impacts of Climate Variation and Sustainable Development in Semi-arid Regions.

Wessels K J, Prince S D, Carroll M, et al. 2007. Relevance of rangeland degradation in semiarid northeastern South Africa to the nonequilibrium theory. Ecological Applications, 17: 815-827.

Whisenant S G. 1999. Repairing Damaged Wildlands: A Process-oriented, Landscape-scale Approach. Cambridge: Cambridge University Press.

White R E. 2005. Principles and Practices of Soil Science: The Soil as a Natural Resource, $4^{\text {th }}$ ed. Chichester: Wiley-Blackwell.

Wilcox B P, Thurow T L. 2006. Emerging issues in rangeland ecohydrology: vegetation change and the water cycle. Rangeland Ecology and Management, 59: 220-224.

Wilcox B P. 2007. Does rangeland degradation have implications for global streamflow? Hydrological Processes, 21: 2961-2964.

World Bank. 2010. Poverty status in Afghanistan: A profile based on the national risk and vulnerability assessment. [2010-07-01]. http://siteresources.worldbank.org/AFGHANISTANEXTN/Resourc es/305984-1264608805475/6739619-1286210806756/AFPovertyRe port.pdf.

World Bank. 2012. Poverty and food security in Afghanistan: Analysis based on national risk and vulnerability assessment. [2014-03-22]. http://moec.gov.af/Content/files/FSR_v7.pdf.

World Bank. 2013. Online database. [2014-03-22]. http://data.worldbank.org/ indic-ator/AG.PRD.LVSK.XD/countries. 